\author{
Agnieszka POLOŃCZYK \\ Uniwersytet Pedagogiczny w Krakowie \\ apolonczyk@up.krakow.pl
}

\title{
STRATEGICZNE UWARUNKOWANIA UŻYCIA SIŁ ZBROJNYCH RFN W LATACH 1955-1989
}

ABSTRACT Strategic conditions of using the armed forces of the Federal Republic of Germany in the period 1955-1989

The aim of the article is to determine the strategic conditions of use of the armed forces of West Germany (the Bundeswehr) since its inception in 1955 until its unification with the National People's Army (1989/1990). In the first part the features of the security environment in Germany have been shown and the main political, military and economic threats identified. As the result of the presented strategic analysis of the state environment as well as the parallel description of the set of values, interests and political goals in the security field, the conceptions of using the Bundeswehr as the army of the national state and a member of the NATO have been characterized.

Key words: security, strategy, use of armed forces, the Bundeswehr

Słowa kluczowe: bezpieczeństwo, strategia, użycie sił zbrojnych, Bundeswehra 


\section{WSTĘP}

Powstała w 1955 r., a więc 10 lat po zakończeniu II wojny światowej, zachodnioniemiecka armia - Bundeswehra - już na samym początku istnienia stanęła wobec trudnego problemu określenia na nowo swojej tożsamości oraz kierunku, w jakim chce podążać. Szeroki dyskurs z udziałem elit politycznych, wojskowych oraz opinii publicznej skutkował opracowaniem szeregu założeń odnośnie do nowych sił zbrojnych, których zapisy znalazły się w Białych Księgach - wydawanych od 1969 r. dokumentach Federalnego Ministerstwa Obrony Republiki Federalnej Niemiec.

W początkowym okresie formowania Bundeswehry, przypadającym na lata 50. oraz początek lat 60 . XX w., rozpoczęto realizację podstawowych założeń, tj. stworzenia armii o charakterze obronnym, opartej na powszechnym obowiązku służby wojskowej i funkcjonującej w sojuszniczych ramach. Plany te korespondowały z obowiązującymi koncepcjami strategicznymi NATO, tj. dokumentem MC 3/5 z 1952 r. ${ }^{1}$ oraz MC 14/2 z 1957 r. ${ }^{2}$ (tzw. strategią zmasowanego odwetu). Ścisłe związki pomiędzy koncepcjami użycia sił zbrojnych RFN a dokumentem strategicznym Sojuszu dostrzec można było jednak dopiero pod koniec lat 60., kiedy to obowiązywać zaczęła kolejna strategia NATO, tj. dokument MC 14/3 z 1968 r. ${ }^{3}$ (tzw. strategia elastycznego reagowania). Nową koncepcję Sojuszu oparto na elastycznych i zrównoważonych opcjach reagowania konwencjonalnego i nuklearnego na agresję o różnych stopniach natężenia. Celem tak skonstruowanej strategii stało się w pierwszej kolejności odstraszanie zniechęcające do agresji, a w razie jej nastąpienia - utrzymanie bezpieczeństwa i integralności obszaru północnoatlantyckiego w ramach koncepcji obrony na wysuniętych rubieżach (wysuniętych liniach obrony). Strategia zakładała możliwość prowadzenia działań wojennych zarówno z wykorzystaniem broni jądrowej, jak i bez niejł. Cechą charakterystyczną nowej koncepcji stało się określenie poziomu gotowości sił bojowych, ich elastyczności, mobilności i zdolności do reagowania oraz sprecyzowanie dodatkowych zadań dla innych sił narodowych przeznaczonych dla NATO.

Dokument z 1968 r. stał się punktem odniesienia podczas tworzenia i doprecyzowywania koncepcji użycia Bundeswehry, czego wyraz znaleźć można we wspomnianych Białych Księgach, z których pierwsza opublikowana została w 1969 r., po tym, jak rok wcześniej przyjęto formalnie wojskowe zadania Bundeswehry w Ustawie

MC 3/5. The Strategic Concept for the Defense of the North Atlantic Area (3 December 1952), [w:] NATO Strategy Documents 1949-1969, red. G.W. Pedlow, Brussels 1997, s. 62-63.

2 MC 14/2. Overall Strategic Concept for the Defence of the NATO Area (23 May 1957), [w:] NATO Strategy Documents..., s. 291-313.

3 MC 14/3. Overall Strategic Concept for the Defence of the NATO Area (16 January 1968), [w:] NATO Strategy Documents..., s. 356-362.

4 Funkcję miecza miały pełnić wojska konwencjonalne wyposażone w broń jądrową, natomiast funkcję tarczy - strategiczne siły jądrowe USA. Użycie broni masowego rażenia dopuszczano jedynie w ostateczności. 
zasadniczej. Kolejne dokumenty Federalnego Ministerstwa Obrony RFN wydawano następnie w niewielkich odstępach czasowych, początkowo co roku (lata 1970, 1971/1972, 1973/1974, 1975/1976, 1979, 1983, 1985). Częstotliwość ukazywania się Białych Ksiąg wynikała z obserwowanych zmiennych warunków środowiska międzynarodowego, a także określanych interesów, z których wynikały cele polityki Niemiec zachodnich i Sojuszu Północnoatlantyckiego w dziedzinie bezpieczeństwa.

W tym miejscu warto zasygnalizować ważność wymogów teoretycznych, z których wynika konstruowanie koncepcji zarówno użycia, jak też rozwoju sił zbrojnych szczególnego instrumentu polityki państwa służącego realizacji jego interesów, tj. precyzowanie:

1. wymogów wynikających z warunków otoczenia państwa (trendów cywilizacyjnych, wyzwań i będących ich efektem zagrożeń oraz szans, jak również sił i słabości badanego obiektu);

2. wymogów organizacyjnych (funkcji spełnianych przez państwo w otoczeniu międzynarodowym oraz środowisku wewnętrznym; misji i wizji państwa jako niezmiennych wskaźników-drogowskazów czynionych wysiłków planistycznych; wreszcie - potrzeb, wartości, interesów oraz wynikających z nich celów polityki bezpieczeństwa państwa) ${ }^{6}$.

Owa praktyka planistyczna ukazana została konsekwentnie w każdej Białej Księdze z lat 1969-1985. I tak, w ramach dokonanej analizy strategicznej otoczenia RFN w niniejszym artykule przedstawiono główne zagrożenia w wymiarach: politycznym, wojskowym oraz ekonomicznym. Opisano je za pomocą macierzy redukcji, kierując się kryterium skali zagrożenia (-1 - wymiar lokalny, -2 - część terytorium państwa, -3 - cale terytorium państwa, -4 - wymiar międzynarodowy) oraz skutków (0 - skutki względnie obojętne, -3 - skutki niekorzystne, -5 - skutki granicznie niekorzystne). Następnie wyodrębniono oraz opisano te zagrożenia, których łączna wartość, stanowiąca iloczyn skali oraz skutków, była najwyższa. Przedstawione w tabelach problemy bezpieczeństwa oraz wartości wskazane zostały przez ekspertów zajmujących się

5 Wystawienie i użycie Bundeswehry precyzują: art. 87a: Federacja powotuje sity zbrojne w celach obronnych; art. 65a: Wtadza rozkazodawcza i dowódcza spoczywa w czasie pokoju w rękach federalnego ministra obrony; oraz art. 115b: Wtadza rozkazodawcza i dowódcza spoczywa w czasie obrony $w$ rękach kanclerza federalnego. Ustawa zasadnicza określa następujące użycie sił zbrojnych: art. 87a ust. 3: Na wypadek obrony i stanu zagrożenia sity zbrojne maja prawo do ochrony obiektów cywilnych i regulowania ruchu drogowego, o ile jest to konieczne dla wykonania zadań stużacych obronie. Ponadto, sitom zbrojnym $w$ stanie obrony $i$ w stanie zagrożenia dla kraju może zostać powierzona ochrona obiektów cywilnych także dla wsparcia zadań policji; sity zbrojne wspótdziataja w takich wypadkach $z$ wtaściwymi wtadzami; ust. 4: W celu obrony przed zagrożeniem istnienia demokratycznego porzadku ustrojowego Federacji lub kraju związkowego Rząd Federalny może, gdy wystąpia przestanki, o których mowa $w$ art. 91 ust. 2, użyć dla wsparcia policji i stużby granicznej sit zbrojnych $w$ celu ochrony obiektów cywilnych $i$ zwalczania zorganizowanych $i$ uzbrojonych sit powstańczych, jeżeli stużby policji i sity granicznej nie wystarczają. Dziatanie sit zbrojnych zostaje wstrzymane na żadanie Bundestagu lub Bundesratu. Cyt. za: Grundgesetz für die Bundesrepublik Deutschland. Werte und Normen für Soldaten, Berlin 2007.

6 Na podstawie: A. Dawidczyk, Planowanie strategii rozwoju sit zbrojnych, Warszawa 2006, s. 73-74, Zeszyty Naukowe - Akademia Obrony Narodowej. 
problematyką bezpieczeństwa ${ }^{7}$. Z kolei w ramach wymogów organizacyjnych określono wartości, interesy oraz cele przenalizowane na podstawie dokumentów strategicznych NATO i Białych Ksiąg Bundeswehry. W rezultacie scharakteryzowano koncepcje użycia Bundeswehry jako narzędzia polityki państwa zachodnioniemieckiego w latach 1955-1989.

\section{WARUNKI OTOCZENIA RFN ORAZ NATO W LATACH 1955-1989}

Wspomnianą analizę strategiczną otoczenia państwa rozpocząć należy od przedstawienia głównych zagrożeń politycznych. Poniższa tabela (tab. 1) ukazuje owe zidentyfikowane zagrożenia polityczne dla RFN i NATO w latach 1955-1989.

Tabela 1. Macierz redukcji zagrożeń politycznych w narodowym oraz sojuszniczym wymiarze w latach 1955-1989

\begin{tabular}{|c|c|c|c|c|c|c|c|c|}
\hline Lp. & $\begin{array}{l}\text { Treść zagrożenia } \\
\text { politycznego w wy- } \\
\text { miarze narodowym }\end{array}$ & 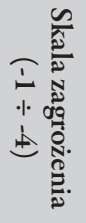 & 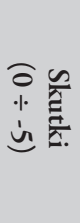 & 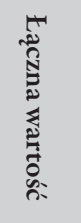 & $\begin{array}{l}\text { Treść zagroże- } \\
\text { nia polityczne- } \\
\text { go w wymiarze } \\
\text { sojuszniczym }\end{array}$ & 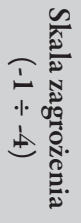 & 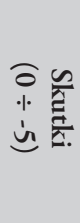 & 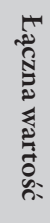 \\
\hline 1. & $\begin{array}{c}\text { Sowiecka interwen- } \\
\text { cja na Węgrzech } \\
(1956)\end{array}$ & $-3,5$ & -3 & 10,5 & $\begin{array}{l}\text { Kryzys sueski } \\
\quad(1956)\end{array}$ & -2 & $-2,5$ & 5 \\
\hline 2. & $\begin{array}{c}\text { Wojna } \\
\text { w Wietnamie } \\
(1957-1973)\end{array}$ & -2 & -2 & 4 & $\begin{array}{c}\text { Wojna } \\
\text { w Wietnamie } \\
(1957-1973)\end{array}$ & -4 & $-4,5$ & 18 \\
\hline 3. & $\begin{array}{l}\text { Kryzys berliński } \\
(1958-1961)\end{array}$ & -4 & -5 & 20 & $\begin{array}{l}\text { Kryzys berliński } \\
(1958-1961)\end{array}$ & -4 & -4 & 16 \\
\hline 4. & $\begin{array}{c}\text { Kryzys kubański } \\
(1962)\end{array}$ & -4 & $-4,5$ & 18 & $\begin{array}{c}\text { Inwazja w Zatoce } \\
\text { Świń (1961) }\end{array}$ & -2 & -4 & 8 \\
\hline 5. & $\begin{array}{l}\text { Praska wiosna } \\
\quad(1968)\end{array}$ & $-3,5$ & -3 & 10,5 & $\begin{array}{c}\text { Kryzys kubański } \\
\text { (1962) }\end{array}$ & -4 & -5 & 20 \\
\hline 8. & $\begin{array}{l}\text { Radziecka in- } \\
\text { terwencja } \\
\text { w Afganistanie } \\
(1979)\end{array}$ & -4 & -2 & 8 & $\begin{array}{c}\text { Radziecka in- } \\
\text { terwencja } \\
\text { w Afganistanie } \\
\text { (1979) }\end{array}$ & -4 & -4 & 16 \\
\hline
\end{tabular}

W artykule przedstawiono wyniki badań przeprowadzonych na potrzeby pracy doktorskiej z 2015 r. wykorzystano uogólnione oceny 15 ekspertów dokonujących analizy strategicznej otoczenia RFN i NATO w latach 1955-1989; byli to eksperci w stopniu doktorów, doktorów habilitowanych oraz profesorów w obszarze: nauk politycznych, nauk o bezpieczeństwie, nauk ekonomicznych oraz nauk historycznych, pracownicy Uniwersytetu Jagiellońskiego, Uniwersytetu Warszawskiego oraz Wyższej Szkoły Policji w Szczytnie. 


\begin{tabular}{|c|c|c|c|c|c|c|c|c|}
\hline Lp. & $\begin{array}{l}\text { Treść zagrożenia } \\
\text { politycznego w wy- } \\
\text { miarze narodowym }\end{array}$ & 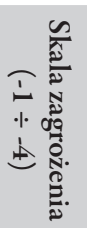 & 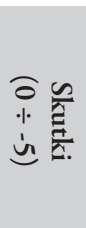 & 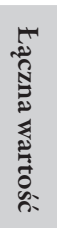 & $\begin{array}{l}\text { Treść zagroże- } \\
\text { nia polityczne- } \\
\text { go w wymiarze } \\
\text { sojuszniczym }\end{array}$ & 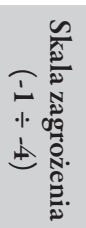 & 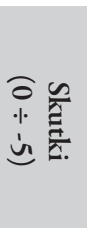 & 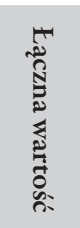 \\
\hline 10. & $\begin{array}{l}\text { Osłabienie prestiżu } \\
\text { międzynarodowego } \\
\text { USA }\end{array}$ & -4 & $-4,5$ & 18 & $\begin{array}{l}\text { Osłabienie prestiżu } \\
\text { międzynarodowego } \\
\text { USA }\end{array}$ & -4 & $-4,5$ & 18 \\
\hline 11. & $\begin{array}{c}\text { Skomplikowana } \\
\text { sytuacja poli- } \\
\text { tyczna w Europie } \\
\text { (Wielka Brytania, } \\
\text { Portugalia, Grecja } \\
\text { i Turcja) }\end{array}$ & -4 & -3 & 12 & $\begin{array}{c}\text { Skomplikowana } \\
\text { sytuacja poli- } \\
\text { tyczna w Europie } \\
\text { (Wielka Brytania, } \\
\text { Portugalia, Grecja } \\
\text { i Turcja) }\end{array}$ & -4 & -4 & 16 \\
\hline 12. & $\begin{array}{c}\text { Przerwanie } \\
\text { radziecko- } \\
\text {-amerykańskich } \\
\text { rokowań } \\
\text { w sprawie broni } \\
\text { jądrowej średniego } \\
\text { i dalekiego zasięgu } \\
(1984-1985)\end{array}$ & -3 & -4 & 12 & $\begin{array}{c}\text { Przerwanie } \\
\text { radziecko- } \\
\text {-amerykańskich } \\
\text { rokowań } \\
\text { w sprawie broni } \\
\text { jądrowej średniego } \\
\text { i dalekiego zasięgu } \\
\text { (1984-1985) }\end{array}$ & -3 & $-4,5$ & 13,5 \\
\hline 13. & $\begin{array}{l}\text { Trudna sytuacja po- } \\
\text { lityczna w krajach } \\
\text { bloku wschodniego } \\
\text { (m.in. w Polsce) }\end{array}$ & -4 & -4 & 16 & $\begin{array}{l}\text { Trudna sytuacja po- } \\
\text { lityczna w krajach } \\
\text { bloku wschodniego } \\
\text { (m.in. w Polsce) }\end{array}$ & $-3,5$ & $-3,5$ & 12,25 \\
\hline
\end{tabular}

Źródło: opracowanie własne na podstawie badań przeprowadzonych w 2015 r.

Powyższa analiza pozwala na stwierdzenie, iż w omawianym okresie największe zagrożenie polityczne dla RFN stanowiły: kryzys berliński (1958-1961), kryzys kubański (1962) oraz osłabienie prestiżu międzynarodowego USA, natomiast dla NATO były to: kryzys kubański (1962), osłabienie prestiżu międzynarodowego USA oraz wojna w Wietnamie (1957-1973).

Z punktu widzenia Niemiec zachodnich tzw. drugi kryzys berliński (1958-1961), rozpoczęty ultimatum radzieckiego przywódcy Nikity Chruszczowa w sprawie uregulowania statusu Berlina Zachodniego, a zakończony budową muru berlińskiego ${ }^{8}$, miał kluczowe znaczenie, jeśli chodzi o wpływ na bezpieczeństwo RFN oraz negatywne następstwa. Co prawda sam byt państwa nie został w bezpośredni sposób zagrożony, lecz wydarzenie to niosło ze sobą zagrożenie interesów politycznych, ekonomicznych oraz społecznych RFN. Do rozwiązania tego problemu zaangażowano znaczną część potencjału wojskowego oraz materialnego państwa. Kryzys berliński

8 Zob. szerzej: T. Diedrich, Die militärische Grenzsicherung an der innerdeutschen Demarkationslinie und der Mauerbau 1961, [w:] Vom Kalten Krieg zur deutschen Einheit. Analysen und Zeitzeugenberichte zur deutschen Militärgeschichte 1945 bis 1995, red. B. Thoss, Oldenbourg 1995, s. 127-144. 
objął swoją skalą całe terytorium Niemiec zachodnich, jednakże było to także wydarzenie o międzynarodowym zasięgu i skutkach (stabilizacja NRD, stopniowe umacnianie się wpływów ZSRR w tej części Europy). W czasie kryzysu stosowano przede wszystkim środki dyplomatyczne (orędzie telewizyjne Johna F. Kennedy'ego na temat zwiększenia uzbrojenia konwencjonalnego, ogłoszenia planu zwiększenia poboru do wojska etc.).

Kryzys kubański (1962), spowodowany tajnym rozmieszczeniem przez ZSRR na Kubie pocisków balistycznych średniego zasięgu, bezpośrednio zagrażających terytorium USA, stanowił niebezpieczeństwo dla bytu oraz ważnych interesów nie tylko Niemiec zachodnich, ale również całego Sojuszu Północnoatlantyckiego. Zaangażowany został niemiecki informacyjny potencjał państwowy (przede wszystkim istotną rolę odgrywała Federalna Służba Wywiadowcza, dysponująca informacjami o miejscach rozmieszczania baz sowieckich rakiet nuklearnych) $)^{9}$, jak również znaczna część potencjału materialnego oraz wojskowego NATO (głównie lotnictwa oraz marynarki USA $^{10}$ ). Kryzys kubański stwarzał zagrożenie dla obszaru całego terytorium Sojuszu. Oprócz stosowania politycznych środków nacisku (rozkazy przechwytywania statków w razie przekraczania rejonów blokady, żądania prezydenta Kennedy'ego usunięcia rakiet z rejonu Kuby etc.) przez cały okres trwania kryzysu istniała groźba użycia broni masowego rażenia, w związku z czym można oceniać ten problem jako posiadający granicznie negatywne skutki dla bezpieczeństwa całego NATO, w tym Niemiec zachodnich.

W latach 1969-1979 zauważyć można było niekorzystne dla bezpieczeństwa RFN oraz NATO osłabienie prestiżu międzynarodowego USA, co było konsekwencją negatywnej oceny udziału Stanów Zjednoczonych w wojnie w Wietnamie. Przegrana z przeciwnikiem słabszym pod względem gospodarczym oraz militarnym wywołała liczne protesty wśród opinii publicznej i społeczeństwa oraz ogólną niechęć do angażowania się militarnego na obszarach trudnych i odległych pod względem geograficznym. Do osłabienia prestiżu przyczynił się także brak realnych sukcesów na frontach Indochin, kryzys polityczny USA (problemy wewnętrzne, afera „Watergate”) oraz kryzys ekonomiczny. W sposób bezpośredni problem ten oddziaływał na stabilność Sojuszu oraz - w sposób pośredni - na bezpieczeństwo Niemiec zachodnich, zagrażając stabilności oraz integralności NATO i tym samym przynależności RFN do Paktu. Zagrożeniu temu przeciwstawiono potencjał materialny i informacyjny - USA wypracowało w 1975 r. nową doktrynę (doktryna Forda), zawierającą zasady polityki USA w rejonie Azji i Pacyfiku (USA jako podstawa i gwarant utrzymania sił oraz suwerenności i niezależności sojuszników azjatyckich). Ponadto kontynuowano proces normalizacji stosunków z Japonią oraz Chinami, a także rozwijano stosunki polityczne i gospodarcze $\mathrm{z}$ Indonezją oraz udzielano tym państwom pomocy wojskowej ${ }^{11}$.

9 B. Greiner, Die Kuba-Krise. Die Welt an der Schwelle zum Atomkrieg, München 2010, s. 46-50.

10 W stan gotowości postawiono około 100 tys. żołnierzy amerykańskich i ponad 180 okrętów wojennych z 85 tys. marines. Tamże, s. 53-55.

11 Zob. szerzej: M. Frey, Geschichte des Vietnamkriegs, München 2006, s. 126-160. 
Kolejnym istotnym problemem bezpieczeństwa była wojna w Wietnamie - z uwagi na fakt, iż jest ona oceniana jako największy konflikt zbrojny po II wojnie światowej, w którym uczestniczyły Stany Zjednoczone, w sposób niekorzystny, choć pośredni, wpływała także na bezpieczeństwo całego NATO. Wojna w Wietnamie oznaczała dla Sojuszu Północnoatlantyckiego zagrożenie interesów politycznych, ekonomicznych oraz społecznych. Zaangażowany został przede wszystkim potencjał wojskowy (zaangażowanie wojsk USA po stronie wojsk Wietnamu Południowego), materialny (dostawa broni i sprzętu, zaopatrzenie logistyczne) oraz informacyjny USA (m.in. kontynuowanie wdrożonego na początku lat 60 . XX w. programu „Phoenix”, koordynowanego przez CIA, siły specjalne USA oraz wojskowy wywiad USA, przeznaczonego do zidentyfikowania i neutralizacji quasi-wywiadowczej struktury dywersyjnej Wietkon$\mathrm{gu}^{12}$ ), choć samo wydarzenie w związku z licznym udziałem koalicji międzynarodowej po stronie USA i po stronie Wietnamu (kraje bloku komunistycznego) miało wymiar międzynarodowy ${ }^{13}$. Skutki dla bezpieczeństwa Sojuszu, ze względu na przegraną Stanów Zjednoczonych, oceniać należy jako niekorzystne.

Analizę strategiczną otoczenia państwa uzupełniają przedstawione poniżej główne zagrożenia wojskowe zidentyfikowane dla RFN i NATO w latach 1955-1989 (tab. 2).

Tabela 2. Macierz redukcji zagrożeń wojskowych w narodowym oraz sojuszniczym wymiarze w latach 1955-1989

\begin{tabular}{|c|c|c|c|c|c|c|c|c|}
\hline Lp. & $\begin{array}{l}\text { Treść zagrożenia } \\
\text { wojskowego w wy- } \\
\text { miarze narodowym }\end{array}$ & 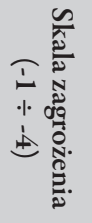 & 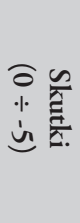 & 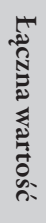 & $\begin{array}{l}\text { Treść zagroże- } \\
\text { nia wojskowe- } \\
\text { go w wymiarze } \\
\text { sojuszniczym }\end{array}$ & 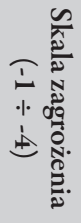 & 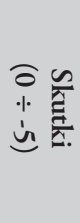 & 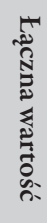 \\
\hline 1. & $\begin{array}{l}\text { Rozbudowa ra- } \\
\text { dzieckiego arse- } \\
\text { nału jądrowego } \\
\text { i termojądrowego } \\
(1955-1969)\end{array}$ & -4 & $-4,5$ & 18 & $\begin{array}{l}\text { Rozbudowa ra- } \\
\text { dzieckiego arse- } \\
\text { nału jądrowego } \\
\text { i termojądrowego } \\
(1955-1969)\end{array}$ & -4 & -5 & 20 \\
\hline 2. & $\begin{array}{c}\text { Rywalizacja } \\
\text { amerykańsko- } \\
\text {-radziecka w ko- } \\
\text { smosie (1955-1969) }\end{array}$ & -4 & 3 & 12 & $\begin{array}{c}\text { Rywalizacja } \\
\text { amerykańsko- } \\
\text {-radziecka w ko- } \\
\text { smosie }(1955-1969)\end{array}$ & -4 & -4 & 16 \\
\hline 3. & $\begin{array}{l}\text { Modernizacja ra- } \\
\text { dzieckiego poten- } \\
\text { cjału rakietowego } \\
(1969-1979)\end{array}$ & -4 & $-4,5$ & 18 & $\begin{array}{c}\text { Modernizacja ra- } \\
\text { dzieckiego poten- } \\
\text { cjału rakietowego } \\
(1969-1979)\end{array}$ & -4 & $-4,5$ & 18 \\
\hline
\end{tabular}

12 Nazwą tą określano partyzantów należących w czasie wojny w Wietnamie do Narodowego Frontu Wyzwolenia Wietnamu Południowego.

13 Zob. szerzej: S.C. Tucker, The Encyclopedia of the Vietnam War. A Political, Social, and Military History, Santa Barbara, Calif. 2011. 


\begin{tabular}{|c|c|c|c|c|c|c|c|c|}
\hline Lp. & $\begin{array}{l}\text { Treść zagrożenia } \\
\text { wojskowego w wy- } \\
\text { miarze narodowym }\end{array}$ & 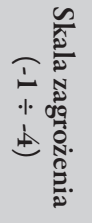 & 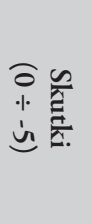 & 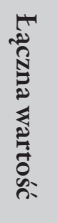 & $\begin{array}{l}\text { Treść zagroże- } \\
\text { nia wojskowe- } \\
\text { go w wymiarze } \\
\text { sojuszniczym }\end{array}$ & 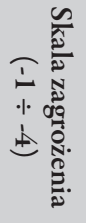 & 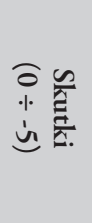 & 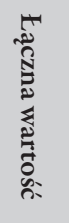 \\
\hline 4. & $\begin{array}{l}\text { Zdolności Układu } \\
\text { Warszawskiego do } \\
\text { rozpoczęcia i pro- } \\
\text { wadzenia szeroko } \\
\text { zakrojonych działań } \\
\text { przeciwko NATO } \\
\text { (agresja nuklearna, } \\
\text { agresja na dużą skalę, } \\
\text { tajne operacje etc.) }\end{array}$ & -4 & -4 & 16 & $\begin{array}{l}\text { Zdolności Układu } \\
\text { Warszawskiego do } \\
\text { rozpoczęcia i pro- } \\
\text { wadzenia szeroko } \\
\text { zakrojonych działań } \\
\text { przeciwko NATO } \\
\text { (agresja nuklearna, } \\
\text { agresja na dużą skalę, } \\
\text { tajne operacje etc.) }\end{array}$ & -4 & -4 & 16 \\
\hline 5. & $\begin{array}{c}\text { Rozmieszczenie na } \\
\text { terytorium NRD } \\
\text { i Czechosłowacji } \\
\text { radzieckich ra- } \\
\text { kiet operacyjno- } \\
\text {-taktycznych } \\
\text { o zwiększonym } \\
\text { zasięgu }\end{array}$ & -4 & -4 & 16 & $\begin{array}{c}\text { Rozmieszczenie na } \\
\text { terytorium NRD } \\
\text { i Czechosłowacji } \\
\text { radzieckich ra- } \\
\text { kiet operacyjno- } \\
\text {-taktycznych } \\
\text { o zwiększonym } \\
\text { zasięgu }\end{array}$ & -4 & -4 & 16 \\
\hline 6. & $\begin{array}{c}\text { Redukcje stanu } \\
\text { liczebnego armii } \\
\text { USA (początek lat } \\
\text { 80.) }\end{array}$ & -2 & -3 & 6 & $\begin{array}{c}\text { Redukcje stanu } \\
\text { liczebnego armii } \\
\text { USA (początek lat } \\
80 . \text { ) }\end{array}$ & -3 & $-3,5$ & 10,5 \\
\hline 7. & $\begin{array}{l}\text { Rozbudowa ra- } \\
\text { dzieckiego systemu } \\
\text { obrony antyrakie- } \\
\text { towej, opartego na } \\
\text { pociskach strate- } \\
\text { gicznych umieszcza- } \\
\text { nych na ruchomych } \\
\text { wyrzutniach }\end{array}$ & 3 & 4 & 12 & $\begin{array}{l}\text { Rozbudowa ra- } \\
\text { dzieckiego systemu } \\
\text { obrony antyrakie- } \\
\text { towej, opartego na } \\
\text { pociskach strate- } \\
\text { gicznych umieszcza- } \\
\text { nych na ruchomych } \\
\text { wyrzutniach }\end{array}$ & -3 & -4 & 12 \\
\hline
\end{tabular}

Źródło: opracowanie własne na podstawie badań przeprowadzonych w $2015 \mathrm{r}$.

Należy zauważyć, iż środowisko bezpieczeństwa zarówno RFN, jak i NATO kształtowały w głównej mierze takie wojskowe zagrożenia, jak: rozbudowa radzieckiego arsenału jądrowego i termojądrowego (1955-1969) oraz modernizacja radzieckiego potencjału rakietowego (1969-1979).

Największym wojkkowym problemem bezpieczeństwa stała się rozbudowa radzieckiego arsenału jądrowego i termojądrowego (budowa rakiet balistycznych, komputerowych systemów naprowadzania, produkcja materiałów rozszczepialnych, w tym wysoko wzbogaconego uranu - HEU) ${ }^{14}$. Oznaczała ona zagrożenie bytu RFN i Sojuszu

14 N. Friedman, Tajne akta zimnej wojny, przeł. P. Stachura, Warszawa 2005, s. 18-22. 
oraz ważnych interesów politycznych, ekonomicznych i społecznych. Do zwalczania tego zagrożenia zaangażowana została niewielka część potencjału materialnego Niemiec z uwagi na fazę formowania się i konsolidacji Bundeswehry (deklaracje stopniowego, kontrolowanego zbrojenia się) oraz gros potencjału militarnego NATO (m.in. w ramach zaangażowania USA w kryzys kubański). Rozbudowa radzieckiego arsenału jądrowego i termojądrowego stała się zagrożeniem obejmującym swoim zasięgiem obszar wszystkich krajów członkowskich NATO (w tym RFN). Ze względu na wielokrotne groźby użycia broni masowego rażenia można mówić o granicznie niekorzystnych skutkach tego zagrożenia dla bezpieczeństwa Niemiec zachodnich oraz Sojuszu Północnoatlantyckiego.

Ponadto istotny problem bezpieczeństwa zarówno w wymiarze narodowym, jak i sojuszniczym stanowiła modernizacja radzieckiego potencjału rakietowego. ZSRR rozbudowywał od połowy lat 70. obronny system antyrakietowy ABM, umieszczając w zachodniej części swojego terytorium trójgłowicowe rakiety średniego zasięgu SS-20, które zastąpiły jednogłowicowe rakiety SS-4 i SS-5. Modernizacja potencjału rakietowego oraz rosnąca radziecka przewaga w dziedzinie broni jądrowej przyczyniły się do zagrożenia integralności, a nawet bytu Sojuszu (w tym Republiki Federalnej), jak również zagrożenia jego interesów (systematycznie rosnące poszerzanie stref wpływów ZSRR i UW), powodując bardzo niekorzystne skutki dla bezpieczeństwa NATO i RFN. W celu zwalczania tego zagrożenia USA rozpoczęły m.in. produkcję i stopniowe udoskonalanie okrętów podwodnych o napędzie nuklearnym, produkcję pocisków UGM-27A Polaris A-1 o zasięgu 1200 mil morskich, stanowiących tymczasową broń na paliwo stałe, produkcję systemów rakietowych opartych na pociskach Poseidon itp. ${ }^{15}$

Analizę otoczenia RFN w latach 1955-1989 kończy przedstawienie zagrożeń ekonomicznych w wymiarze narodowym oraz sojuszniczym (tab. 3).

Tabela 3. Macierz redukcji zagrożeń ekonomicznych w narodowym oraz sojuszniczym wymiarze w latach 1955-1989

\begin{tabular}{|c|c|c|c|c|c|c|c|c|}
\hline Lp. & $\begin{array}{l}\text { Treść zagrożenia } \\
\text { ekonomiczne- } \\
\text { go w wymiarze } \\
\text { narodowym }\end{array}$ & 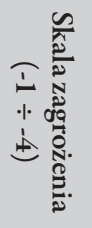 & 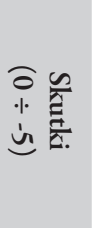 & 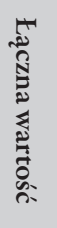 & $\begin{array}{l}\text { Treść zagrożenia } \\
\text { ekonomiczne- } \\
\text { go w wymiarze } \\
\text { sojuszniczym }\end{array}$ & 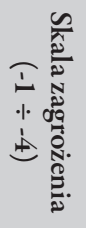 & 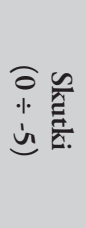 & 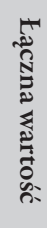 \\
\hline 1. & $\begin{array}{c}\text { Standaryzacja broni } \\
\text { i sprzętu ZSRR, } \\
\text { modernizacja so- } \\
\text { wieckiego arsenału } \\
\text { wojskowego, do- } \\
\text { skonalenie i pro- } \\
\text { dukcja uzbrojenia } \\
\text { (1955-1969) }\end{array}$ & -4 & -4 & 16 & $\begin{array}{c}\text { Standaryzacja broni } \\
\text { i sprzętu ZSRR, } \\
\text { modernizacja so- } \\
\text { wieckiego arsenału } \\
\text { wojskowego, do- } \\
\text { skonalenie i pro- } \\
\text { dukcja uzbrojenia } \\
\text { (1955-1969) }\end{array}$ & -4 & -4 & 16 \\
\hline
\end{tabular}

15 N. Polmar, K.J. Moore, Cold War Submarines. The Design and Construction of U.S. and Soviet Submarines, Washington 2003, s. 77-90. 


\begin{tabular}{|c|c|c|c|c|c|c|c|c|}
\hline Lp. & $\begin{array}{l}\text { Treść zagrożenia } \\
\text { ekonomiczne- } \\
\text { go w wymiarze } \\
\text { narodowym }\end{array}$ & 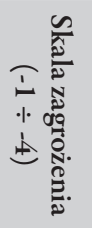 & 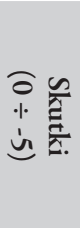 & 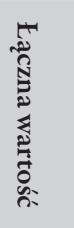 & $\begin{array}{l}\text { Treść zagrożenia } \\
\text { ekonomiczne- } \\
\text { go w wymiarze } \\
\text { sojuszniczym }\end{array}$ & 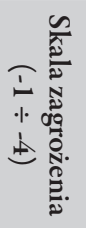 & 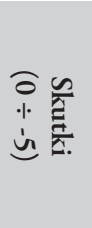 & 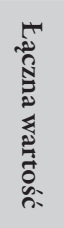 \\
\hline 2. & $\begin{array}{l}\text { Rosnące wydatki } \\
\text { ZSRR na zbrojenia, } \\
\text { szczególnie na roz- } \\
\text { budowę obronnego } \\
\text { systemu antyrakie- } \\
\text { towego ABM oraz } \\
\text { produkcję poci- } \\
\text { sków rakietowych } \\
(1955-1969)\end{array}$ & -4 & -4 & 16 & $\begin{array}{l}\text { Rosnące wydatki } \\
\text { ZSRR na zbrojenia, } \\
\text { szczególnie na roz- } \\
\text { budowę obronnego } \\
\text { systemu antyrakie- } \\
\text { towego ABM oraz } \\
\text { produkcję poci- } \\
\text { sków rakietowych } \\
(1955-1969)\end{array}$ & -4 & $-4,5$ & 18 \\
\hline 3. & $\begin{array}{l}\text { Uzależnienie } \\
\text { Europy Zachodniej } \\
\text { od dostaw materia- } \\
\text { tów z obszarów za- } \\
\text { morskich, dostępu } \\
\text { do baz oraz infra- } \\
\text { struktury wojsko- } \\
\text { wej (1955-1969) }\end{array}$ & -3 & -3 & 9 & $\begin{array}{l}\text { Rosnące wydatki } \\
\text { ZSRR na obronę } \\
\text { i pomoc dla krajów } \\
\text { Trzeciego Świata } \\
\text { (1955-1969) }\end{array}$ & -4 & -3 & 12 \\
\hline 4. & $\begin{array}{c}\text { Kryzys walutowy } \\
\text { lat } 70 .\end{array}$ & -2 & -3 & 6 & $\begin{array}{c}\text { Kryzys walutowy } \\
\text { lat } 70 .\end{array}$ & -3 & $-3,5$ & 10,5 \\
\hline 5. & $\begin{array}{c}\text { Światowy kryzys } \\
\text { paliwowy (1973, } \\
1979)\end{array}$ & -2 & -3 & 6 & $\begin{array}{c}\text { Światowy kryzys } \\
\text { paliwowy (1973, } \\
1979)\end{array}$ & -3 & -4 & 12 \\
\hline 6. & $\begin{array}{l}\text { Okres rozwoju go- } \\
\text { spodarczego ZSRR } \\
\text { oraz krajów bloku } \\
\text { wschodniego w la- } \\
\text { tach } 70 .\end{array}$ & -3 & $-3,5$ & 10,5 & $\begin{array}{c}\text { Prosperita go- } \\
\text { spodarcza ZSRR } \\
\text { oraz krajów bloku } \\
\text { wschodniego w la- } \\
\text { tach } 70 .\end{array}$ & -3 & $-3,5$ & 10,5 \\
\hline 7. & $\begin{array}{l}\text { Rosnące wydatki } \\
\text { niektórych państw } \\
\text { NATO (w tym } \\
\text { RFN) na pomoc } \\
\text { rozwojową i eksport } \\
\text { broni do krajów } \\
\text { Trzeciego Świata }\end{array}$ & -3 & -4 & 12 & $\begin{array}{l}\text { Rosnące wydatki } \\
\text { niektórych państw } \\
\text { NATO na pomoc } \\
\text { rozwojową i eksport } \\
\text { broni do krajów } \\
\text { Trzeciego Świata }\end{array}$ & -3 & -4 & 12 \\
\hline 8. & $\begin{array}{l}\text { Zamrożenie wydat- } \\
\text { ków USA na nowo- } \\
\text { czesne uzbrojenie } \\
\text { armii (początek lat } \\
\text { 80.) }\end{array}$ & -3 & -3 & 9 & $\begin{array}{l}\text { Zamrożenie wydat- } \\
\text { ków USA na nowo- } \\
\text { czesne uzbrojenie } \\
\text { armii } \\
\text { (początek lat } 80 . \text { ) }\end{array}$ & -3 & -4 & 12 \\
\hline
\end{tabular}

Źródło: opracowanie własne na podstawie badań przeprowadzonych w $2015 \mathrm{r}$. 
Wśród sklasyfikowanych problemów ekonomicznych do największych dla RFN oraz Sojuszu Północnoatlantyckiego należały przede wszystkim: standaryzacja broni i sprzętu ZSRR w latach 1955-1969 oraz rosnące wydatki ZSRR na zbrojenia w latach 1955-1969.

Zagrożeniem ekonomicznym o najbardziej negatywnych skutkach była obserwowana w latach 1955-1989 standaryzacja radzieckiej broni i sprzętu, modernizacja arsenału wojskowego ZSRR oraz doskonalenie i produkcja uzbrojenia. Podkreślić należy sukcesywną, następującą od 1946 r., modernizację armii ZSRR (zmiany techniczne, strukturalne, rozwijanie zgrupowań sił pancernych i zmechanizowanych na europejskich TDW, dozbrajanie lotnictwa radzieckiego w samoloty odrzutowe, zwiększanie liczebności wojsk powietrzno-desantowych, rozwój radzieckiej floty wojennej, rozbudowa agentur wywiadowczych m.in. w RFN, Wielkiej Brytanii, USA) ${ }^{16}$. Powodowało to stałe zagrożenie nie tylko bytu Niemiec Zachodnich i NATO, ale także ich interesów politycznych, ekonomicznych i społecznych. Temu zagrożeniu Sojusz i RFN przeciwstawiały znaczną część swojego potencjału wojskowego, materialnego oraz informacyjnego (standaryzacja broni i sprzętu państw Sojuszu, wzrost wydatków na zbrojenia, szkolenie żołnierzy, podnoszenie ich kwalifikacji itp.). Ze względu na możliwe skutki można mówić o zagrożeniu nie tylko terytorium RFN, ale i całego NATO.

W latach 1955-1969 obserwować można było również rosnące wydatki ZSRR na zbrojenia ${ }^{17}$ (choć po roku 1964 gospodarka ZSRR zwolniła tempo wzrostu). Wydatki ZSRR na zbrojenia w miliardach dolarów przedstawiają się następująco: 1962 - 49,9; 1963 - 54,7; 1964 - 48,7; 1965 - 62,3; 1966 - 69,7; 1967 - 80,9; 1968 - 85,4; 1969 89,8. Wyścig zbrojeń stanowił istotne zagrożenie bytu RFN i całego NATO, jak również zagrożenie ważnych interesów politycznych, społecznych oraz ekonomicznych. Temu problemowi RFN oraz NATO przeciwstawiały znaczną część swojego potencjału informacyjnego oraz materialnego (Niemcy zachodnie zwiększyły w latach 1955-1968 budżet na obronę od wysokości 0,1 do 18,055 mld marek $)^{18}$. Rosnące wydatki na zbrojenia ZSRR stały się problemem dla całej społeczności międzynarodowej (w tym państw Sojuszu).

Powyższe wskazanie najbardziej istotnych zagrożeń w wymiarach: politycznym, wojskowym oraz ekonomicznym w latach 1955-1989 pozwala na konstatację, iż w większości problemy oddziałujące w bezpośredni sposób na bezpieczeństwo NATO rzutowały - bezpośrednio lub pośrednio - na stabilność i bezpieczeństwo Republiki Federalnej. Co istotne, zagrożenia zidentyfikowane w otoczeniu bezpośrednim RFN również nie pozostawały bez wpływu na bezpieczeństwo całego Sojuszu. Zauważyć należy zatem silną wzajemną zależność polityczną, wojskową oraz ekonomiczną Sojuszu i RFN, co z kolei nie pozostaje bez znaczenia w procesie określania interesów, celów oraz koncepcji użycia Bundeswehry jako armii o charakterze sojuszniczym.

16 Zob. szerzej m.in.: I. Drogowoz, Pancerna potega ZSRR 1945-1991, Warszawa 2001, s. 15-80.

17 Soviet Economic Performance 1966-67. Materials Prepared for the Subcommittee, Washington 1969, s. 10-19.

18 Weissbuch 1969 zur Verteidigungspolitik der Bundesregierung, Bonn 1969, s. 68. 


\section{WYMOGI ORGANIZACYJNE RFN ORAZ NATO W LATACH 1955-1989}

Równolegle do zaprezentowanej analizy strategicznej otoczenia państwa/Sojuszu wskazać należy narodowe i sojusznicze wartości zapisane w Białych Księgach RFN i dokumentach strategicznych NATO, dostarczające treści na użytek kolejnych etapów procesu planistycznego. Warto zaznaczyć, iż w każdej ze wspomnianych Białych Ksiąg Bundeswehry od 1969 r. pojawia się zapis tych samych wartości narodowych RFN. Należy zauważyć, iż wartości te zakotwiczone są w systemie wartości NATO, zapisanym w Traktacie Północnoatlantyckim ${ }^{19}$, stanowiąc jego skonkretyzowanie przeniesione na grunt niemiecki. Wartości narodowe i sojusznicze przedstawia tab. 4.

Tabela 4. Wartości narodowe RFN i sojusznicze NATO w latach 1955-1989

\section{WARTOŚCI NARODOWE RFN \\ 1. Utrzymywanie i kształtowanie ładu pokojo- wego w Europie i na świecie rozumianego jako brak wojen. \\ 2. Zachowanie niezależności i wolności \\ Republiki Federalnej. \\ 3. Ochrona integralności i nienaruszalności jej terytorium.}

4. Zagwarantowanie jej obywatelom życia w bezpiecznym i praworządnym państwie, respektującym prawa człowieka i opartym na porządku demokratycznym*.

\section{WARTOŚCI SOJUSZNICZE NATO}

1. Pragnienie życia w pokoju ze wszystkimi narodami i rządami.

2. Ochrona wolności, wspólnego dziedzictwa i cywilizacji swych narodów, opartych na zasadach demokracji, wolności jednostki i praworządności.

3. Dążenie do umacniania stabilizacji i dobrobytu na obszarze północnoatlantyckim.

4. Gotowość do połączenia swych wysiłków $\mathrm{w}$ celu zbiorowej obrony oraz zachowania pokoju i bezpieczeństwa**.

* Bundesministerium der Verteidigung: Weissbuch 1969 zur Verteidigungspolitik der Bundesregierung, Bonn 1969, s. 11-12; Weißbuch 1970 zur Sicherheit der Bundesrepublik Deutschland und zur Lage der Bundeswehr, Bonn 1970, s. 3-4, 9, 11-12; Weißbuch 1971/1972 zur Sicherheit der Bundesrepublik Deutschland und zur Entwicklung der Bundeswehr, Bonn 1971, s. 3-6; Weißbuch 1973/1974zur Sicherheit der Bundesrepublik Deutschland und zur Entwicklung der Bundeswehr, Bonn 1974, s. 3-5, 7; Weißbuch 1975/1976 zur Sicherheit der Bundesrepublik Deutschland und zur Entwicklung der Bundeswehr, Bonn 1976, s. 3-5; Weißbuch 1979 zur Sicherheit der Bundesrepublik Deutschland und zur Entwicklung der Bundeswehr, Bonn 1979, s. 3-4, 11; Weißbuch 1983 zur Sicherheit der Bundesrepublik Deutschland, Bonn 1983, s. 3-4; Weißbuch 1985 zur Lage und Entwicklung der Bundeswehr, Bonn 1985, s. 3-5, 14.

** MC 3/5. The Strategic Concept for the Defense of the North Atlantic Area (3 December 1952), [w:] NATO Strategy Documents 1949-1969, red. G.W. Pedlow, Brussels 1997, s. 59; MC 14/2. Overall Strategic Concept for the Defence of the NATO Area (23 May 1957), [w:] NATO Strategy Documents..., s. 283; MC 14/3. Overall Strategic Concept for the Defence of the NATO Area (16 January 1968), [w:] NATO Strategy Documents..., s. 349.

Źródło: opracowanie własne.

Z powyższych wartości wynikają interesy narodowe RFN, które wpisują się w szerszy kontekst interesów sojuszniczych wskazanych w koncepcjach strategicznych NATO. Owe zidentyfikowane interesy narodowe i sojusznicze ukazano w tabeli poniżej (tab. 5).

19 Traktat Pótnocnoatlantycki sporządzony w Waszyngtonie dnia 4 kwietnia 1949 r., Dz.U. 2000, nr 87, poz. 970. Do wartości tych nawiązują wszystkie koncepcje strategiczne NATO. 
Tabela 5. Interesy narodowe RFN i sojusznicze NATO w latach 1955-1989

\section{INTERESY NARODOWE RFN}

1. Rozwiązywanie zaistniałych w Europie problemów na drodze pokojowej, przede wszystkim tzw. kwestii niemieckiej, przy współpracy w ramach NATO i Narodów Zjednoczonych, oraz utrzymywanie równowagi nuklearnej.

2. Dążenie do zachowania pokoju poprzez rozwój przyjaznych stosunków z ZSRR, pogłębianie współpracy z krajami Układu Warszawskiego oraz uregulowanie kwestii dotyczących kontroli zbrojeń.

3. Dążenie do osiągnięcia stabilizacji ekonomicznej poprzez współpracę z partnerami gospodarczymi, m.in. krajami Trzeciego Świata.

4. Prowadzenie polityki opartej na równowadze strategicznej i wojskowej, polityki odprężenia, ograniczania konfliktów i zwalczania kryzysów oraz utrzymywania z partnerami stosunków politycznych, opartych na klarownych i przewidywalnych zasadach.

5. Prowadzenie aktywnej polityki pokojowej polegającej na: zapobieganiu konfliktom zbrojnym, osiągnięciu poczucia bezpieczeństwa i stabilizacji we wszystkich państwach Europy na równym poziomie i rozwijaniu współpracy z państwami Europy Wschodniej, ochronie przed zagrożeniami oraz woli współpracy w ramach NATO*.

\section{INTERESY SOJUSZNICZE NATO}

1. Zapobieżenie wybuchowi konfliktu zbrojnego oraz zapewnienie na wypadek wojny skutecznego zastosowania wojskowej i przemysłowej siły państw członkowskich w ramach wspólnej obrony.

2. Zapobieżenie wojnie dzięki skutecznemu odstraszaniu zniechęcającemu do agresji oraz poprzez utrzymywanie odpowiedniej czynnej siły wojskowej, za sprawą oszczędności wysiłku, zasobów i siły żywej.

3. Zapewnianie własnej obrony w zgodności $\mathrm{z}$ nadrzędnym założeniem ochrony terytorium traktatowego, a w ramach uzgodnień - także realizacji innych zobowiązań obronnych.

4. Zachowanie dostatecznej elastyczności wojskowej umożliwiającej prowadzenie polityki zachowania pokoju i bezpieczeństwa na obszarze NATO, polegającej na przeciwdziałaniu wrogim wpływom ZSRR.

5. Przeciwstawienie się potencjalnej, grożącej lub faktycznej agresji przez stosowne siły NATO od tajnych operacji do pełnej wojny nuklearnej, jak również zapewnienie siły wojskowej wspierającej osiąganie celów Sojuszu i przestrzeganie jego zasad**.

* Bundesministerium der Verteidigung: Weissbuch 1969 zur Verteidigungspolitik der Bundesregierung, Bonn 1969, s. 12-16; Weisbuch 1970 zur Sicherheit der Bundesrepublik Deutschland und zur Lage der Bundeswehr, Bonn 1970, s. 11-13, 15-17; Weisbuch 1971/1972 zur Sicherheit der Bundesrepublik Deutschland und zur Entwicklung der Bundeswehr, Bonn 1971, s. 6-13; Weisbuch 1973/1974 zur Sicherheit der Bundesrepublik Deutschland und zur Entwicklung der Bundeswehr, Bonn 1974, s. 7-10, 18-27, 41-47; Weisbuch 1975/1976 zur Sicherheit der Bundesrepublik Deutschland und zur Entwicklung der Bundeswehr, Bonn 1976, s. 49-54, 59-77; Weisbuch 1979 zur Sicherheit der Bundesrepublik Deutschland und zur Entwicklung der Bundeswehr, Bonn 1979, s. 41-55, 85-87; Weisbuch 1983 zur Sicherheit der Bundesrepublik Deutschland, Bonn 1983, s. 13-20, 69-71, 112-115; Weisbuch 1985 zur Lage und Entwicklung der Bundeswehr, Bonn 1985, s. 27-35.

** MC 3/5. The Strategic Concept for the Defense of the North Atlantic Area (3 December 1952), [w:] NATO Strategy Documents 1949-1969, red. G.W. Pedlow, Brussels 1997, s. 59-60; MC 14/2. Overall Strategic Concept for the Defence of the NATO Area (23 May 1957), [w:] NATO Strategy Documents..., s. 283284; MC 14/3. Overall Strategic Concept for the Defence of the NATO Area (16 January 1968), [w:] NATO Strategy Documents..., s. 349.

Źródło: opracowanie własne.

Interesy narodowe RFN oraz wspólnotowe NATO, odniesione do warunków funkcjonowania państwa/Sojuszu w latach 1955-1989, pozwalają na identyfikację celów Republiki Federalnej oraz Paktu Północnoatlantyckiego we wspomnianych ramach czasowych. Przedstawiają się one następująco (tab. 6). 
Tabela 6. Cele RFN i cele NATO w latach 1955-1989

\section{CELE RFN}

1a. Aktywny udział we wspólnej obronie NATO w Europie Środkowej (obrona na wysuniętych rubieżach).

1b. Realizacja strategii „elastycznego reagowania”, wymagającej wyposażenia sił zbrojnych w środki do zwalczania broni nuklearnej. 1c. Dalsza, konsekwentna rezygnacja z produkcji broni $\mathrm{ABC}$ oraz niemiecki udział w gremiach planistycznych Sojuszu Północnoatlantyckiego.

2a. Realizacja polityki wschodniej oraz polityki odprężenia.

2b. Wypełnianie zobowiązań w zakresie ograniczania zbrojeń zawartych w układach paryskich oraz Układzie o nierozprzestrzenianiu broni jądrowej (NPT).

2c. Dążenie do podpisania amerykańsko-radzieckiego Układu o ograniczaniu zbrojeń strategicznych (SALT) oraz kontynuacja rozmów w sprawie Wzajemnej i Zrównoważonej Redukcji Sił Konwencjonalnych i aktywne wspieranie dążeń społeczności międzynarodowej do rezygnacji z posiadania broni $\mathrm{ABC}$.

\section{CELE NATO}

1a. Dążenie do osiągnięcia odpowiedniej siły wojskowej w ramach wspólnego planowania obronnego za sprawą oszczędności wysiłków, środków i czynnika ludzkiego oraz maksymalnego rozwinięcia potencjału wojskowego przez każde państwo członkowskie zgodnie z ogólnymi planami strategicznymi przy uwzględnieniu odbudowy gospodarczej i osiągnięcia stabilności gospodarczej jako ważnych aspektów ich bezpieczeństwa.

1b. Wypracowanie porozumień w sprawie kolektywnej samoobrony państw-stron Traktatu Północnoatlantyckiego.

1c. Wypełnianie szczególnych zadań i misji przez państwa, które dysponują szczególnymi zdolnościami lub znajdują się w istotnym z punktu geograficznego położeniu.

1d. W czasie pokoju - koordynacja potencjału wojskowego i gospodarczego w celu stworzenia potężnego czynnika odstraszania państwa/grupy państw zagrażających pokojowi, niezależności lub stabilności NATO, jak również opracowywanie planów do realizacji na wypadek wojny.

2a. Rozwinięcie siły wojskowej każdego państwa członkowskiego w sposób maksymalnie zbieżny $z$ koncepcją strategiczną NATO przy uwzględnieniu odbudowy gospodarczej i osiągnięcia stabilności gospodarczej jako ważnych aspektów ich bezpieczeństwa.

2b. Wypełnianie szczególnych zadań i misji przez państwa, które dysponują szczególnymi zdolnościami lub znajdują się w istotnym z punktu geograficznego położeniu (konkretne strategiczne cele dotyczące Europy Zachodniej, Skandynawii, Europy Południowej, Wysp Brytyjskich, Ameryki Północnej, północnej części Oceanu Atlantyckiego, Islandii, kanału La Manche i Morza Północnego, Morza Śródziemnego, Portugalii oraz Algierii).

2c. Rozwijanie środków rozpoznania agresji ZSRR (lądowej, morskiej lub powietrznej) oraz środków doskonalenia systemu umożliwiającego szybkie przekazywanie informacji w tej sprawie.

2d. Koordynowanie planów, doktryn i praktyk oraz dokonywanie standaryzacji zasobów materialnych i sprzętu wojskowego, 


\section{CELE RFN}

3a. Aktywny udział w politycznej współpracy w ramach Unii Zachodnioeuropejskiej.

3b. Wspieranie rosnącego zaangażowania politycznego w obszarze Bliskiego i Dalekiego Wschodu oraz podpisywanie umów zwiększających dostawy surowców na obszar europejski.

3c. Wspieranie polityczno-wojskowej współpracy pomiędzy NATO a Wspólnotą Europejską w ramach powstałej w 1968 r. EUROGRUPY będącej europejskim filarem NATO.

4a. Wspieranie realizacji wspólnych interesów NATO na obszarze Bliskiego Wschodu.

4b. Wspieranie polityki Sojuszu polegającej na przeciwdziałaniu kryzysom ekonomicznym, w tym problemom z rosnącym uzależnieniem energetycznym i surowcowym od państw Bliskiego i Dalekiego Wschodu.

4c. Wspieranie południowo-wschodniej flanki NATO w związku z niestabilną sytuacją polityczną (Grecja, Turcja, Portugalia).

4d. Dążenie do wzmacniania sily obronnej NATO poprzez wprowadzenie standaryzacji w zakresie broni, sprzętu, dowodzenia, logistyki oraz kształcenia wojskowych z państw Sojuszu.

5a. Prowadzenie aktywnej polityki gospodarczej polegającej na podpisywaniu umów handlowych (import, eksport z krajami Afryki, Karaibów i Pacyfiku) oraz wspieraniu pomocy rozwojowej dla krajów Trzeciego Świata*.

\section{CELE NATO}

3a. Odpowiednie zorganizowanie, nastawienie, wyposażenie i wyszkolenie sił NATO gotowych na przeciwstawienie się każdej formie agresji ZSRR, a w przypadku agresji - zachowanie lub przywrócenie integralności i bezpieczeństwa obszaru północnoatlantyckiego $\mathrm{z}$ wykorzystaniem takich sił, jakie mogą być potrzebne do realizacji koncepcji obrony na wysuniętych rubieżach**.

* Bundesministerium der Verteidigung: Weissbuch 1969 zur Verteidigungspolitik der Bundesregierung, Bonn 1969, s. 11, 17-23; Weisbuch 1970 zur Sicherheit der Bundesrepublik Deutschland und zur Lage der Bundeswehr, Bonn 1970, s. 11-23,33-35; Weisbuch 1971/1972 zur Sicherheit der Bundesrepublik Deutschland und zur Entwicklung der Bundeswehr, Bonn 1971, s. 18-23; Weisbuch 1973/1974 zur Sicherheit der Bundesrepublik Deutschland und zur Entwicklung der Bundeswehr, Bonn 1974, s. 18-28, 43-47; Weisbuch 1975/1976 zur Sicherheit der Bundesrepublik Deutschland und zur Entwicklung der Bundeswehr, Bonn 1976, s. 56-57; Weisbuch 1979 zur Sicherheit der Bundesrepublik Deutschland und zur Entwicklung der Bundeswehr, Bonn 1979, s. 41-84; Weisbuch 1983 zur Sicherheit der Bundesrepublik Deutschland, Bonn 1983, s. 119-135; Weisbuch 1985 zur Lage und Entwicklung der Bundeswehr, Bonn 1985, s. 101-135.

** MC 3/5. The Strategic Concept for the Defense of the North Atlantic Area (3 December 1952), [w:] NATO Strategy Documents 1949-1969, red. G.W. Pedlow, Brussels 1997, s. 59, 61; MC 14/2. Overall Strategic Concept for the Defence of the NATO Area (23 May 1957), [w:] NATO Strategy Documents..., s. 283-284, 288-313; MC 14/3. Overall Strategic Concept for the Defence of the NATO Area (16 January 1968), [w:] NATO Strategy Documents..., s. 349-350.

Źródło: opracowanie własne. 
Podsumowując tę część rozważań, należy zauważyć, iż interesy oraz cele polityki RFN w latach 1955-1989 pozostawały w ścisłej zależności od szerzej zidentyfikowanych interesów oraz celów NATO. W opisanych warunkach otoczenia relacja ta oznaczała z jednej strony realizowanie szerokiego spektrum celów narodowych w oparciu o rozporządzalne zasoby służące polityce suwerennego państwa, $\mathrm{z}$ drugiej - poruszanie się w ramach szerszych, ogólnych, ograniczonych głównie do obrony wspólnej celów NATO, których osiąganie służyć miało zapewnieniu bezpieczeństwa samej RFN oraz innych państw wchodzących w skład Sojuszu. Nie można zatem wskazywać tu na hierarchiczność, nadrzędność bądź interesów narodowych nad sojuszniczymi, bądź odwrotnie, a raczej na ich wynikowość, współzależność i wzajemne powiązania. Bez wątpienia rezultatem tak wyodrębnionych celów stało się określenie koncepcji użycia sił zbrojnych RFN.

\section{KONCEPCJE UŻYCIA BUNDESWEHRY W OKRESIE 1955-1989}

Logiczny ciąg, w ramach którego zidentyfikowano narodowe i sojusznicze wartości, interesy oraz cele, pozwala na zarysowanie koncepcji użycia Bundeswehry w omawianych latach. Poniżej przedstawiono owe koncepcje wyodrębnione w poszczególnych Białych Księgach.

W pierwszej koncepcji użycia Bundeswehry (tab. 7) podkreślony został charakter defensywny armii oraz znaczenie współpracy komponentów wojskowych i cywilnych podczas obrony powszechnej. Użycie poszczególnych rodzajów sił zbrojnych stanowi odniesienie do koncepcji strategicznej NATO z 1968 r. W dokumencie zaakcentowano główną rolę sił lądowych, wzmocnionych o jednostki powietrzne, ich mobilny charakter oraz gotowość operacyjną. Siłom powietrznym, włączonym w organizację sił powietrznych NATO, przyporządkowano zadania rozpoznania, obrony przydzielonych obszarów oraz odstraszania w ramach taktycznych operacji powietrznych. Siły morskie z kolei uczyniono odpowiedzialnymi za obronę w rejonie Morza Bałtyckiego oraz Morza Północnego.

Kolejne dwie koncepcje użycia Bundeswehry z lat 1970 oraz 1971/1972 (tab. 8) precyzują zadania nowej armii RFN w stanie pokoju, kryzysu, zagrożenia oraz obrony, ponownie dowodząc defensywnego charakteru sił zbrojnych. Dokumenty konkretyzują ramy funkcjonowania Bundeswehry w Sojuszu (struktura, planowanie, dowodzenie) oraz formułują wytyczne dotyczące obrony terytorialnej. Szczegółowe użycie poszczególnych rodzajów sił zbrojnych zostaje powtórzone zgodnie z Białą Księgą z 1969 r.

Koncepcja użycia Bundeswehry z lat 1973/1974 (tab. 9) nawiązująca do fazy odprężenia lat 70. przedstawia siły zbrojne jako instrument służący realizacji tejże polityki. Wskazanie na siły zbrojne jako narzędzie obrony nie tylko narodowej, ale także sojuszniczej oraz podkreślenie wkładu ilościowego i jakościowego w system obrony kolektywnej świadczyć może o postępującej fazie konsolidacji wpływów armii w Sojuszu. $\mathrm{Z}$ uwagi na niewielkie odstępy czasowe pomiędzy powstałymi dokumentami szczegółowe użycie sił lądowych, powietrznych i morskich zostało powtórzone zgodnie z literą wcześniejszych Białych Ksiąg oraz uzupełnione o istotne, dodatkowe zadania (m.in. podkreślenie roli sił terytorialnych, współdziałanie sił powietrznych i morskich, rola sił morskich w rozpoznaniu i in.). 
Tabela 7. Koncepcja użycia Bundeswehry zgodnie z Białą Księgą z 1969 r. ${ }^{20}$

\section{Ogólna koncepcja użycia sił zbrojnych RFN}

Znaczenie podkreślanych w koncepcji NATO mobilnych sił obronnych, wzmocnionych zza oceanu, zdolnych do rozpoczęcia ataku. Obrona powszechna (wojskowa oraz cywilna) - oznacza gotowość do obrony RFN i jej obywateli, zapewnionej przez odpowiednią ilość sił zbrojnych i podtrzymywanie ich swobody do działań operacyjnych. Istotną rolę odgrywa w tym względzie współpraca komponentu cywilnego z wojskowym*.

Powodzenie wkładu wojskowego RFN zależne jest od wewnętrznej stabilności kraju, tj. dalszego zabezpieczania linii łączności, terenów i obiektów istotnych z punktu widzenia obronności, używania narodowych źródeł pomocy oraz zaopatrzenia z głębi kraju.

\section{Szczegółowe użycie sił lądowych, powietrznych i morskich}

Struktura: siły lądowe, siły powietrzne, siły morskie, obrona terytorialna (1 lutego 1969 r. rozpoczęto fuzję obrony terytorialnej i sił lądowych), centralne urzędy wojskowe Bundeswehry.

Siły lądowe (Heer): zgodnie z koncepcją strategiczną NATO siły lądowe stanowią istotny komponent wojskowy zdolny do odparcia ograniczonej agresji; jednostki powinny dysponować mobilnością, siłą ognia i gotowością operacyjną; ich uzupełnienie stanowią jednostki powietrzne zdolne do szybkiego przemieszczania się w celu obrony w razie niespodziewanego ataku wroga; siły lądowe mają za zadanie współpracować z siłami powietrznymi, które przejmują zadania związane z ochroną przestrzeni powietrznej; podkreśla się elastyczny system sprowadzania rezerwistów włączanych w jednostki sił lądowych.

Siły powietrzne (Luftwaffe): podporządkowane nawet w czasie pokoju organizacji sił powietrznych NATO; ich wkład w odstraszanie następuje poprzez umiejętność prowadzenia taktycznych operacji powietrznych, obronę powietrzną przydzielonych obszarów, rozpoznanie, walkę przeciwko wrogim siłom powietrznym, blokadę strefy walk w głębi wrogich obszarów operacyjnych oraz wsparcie powietrzne wojsk lądowych.

Siły morskie (Marine) posiadają następujące zadania: obrona przed atakami z morza, wspólna ochrona dostępu do Morza Bałtyckiego, zabezpieczanie ruchu zaopatrzeniowego przez morze, wsparcie operacji sił lądowych na obszarach przybrzeżnych, pilnowanie praw Republiki Federalnej na morzu, obrona niemieckiej żeglugi przed atakiem lub zewnętrzną ingerencją. Obszary prowadzenia operacji przez marynarkę RFN: Morze Bałtyckie, cieśniny Kattegat i Skagerrak, wschodnia część Morza Północnego. Podkreśla się szczególne wyszkolenie jednostek powietrznych marynarki wojennej do prowadzenia wojny morskiej z powietrza.

* Bericht über das Konzept der zivilen Verteidigung und das Programm für die Zeit bis 1972, Bonn 1968. Źródło: opracowanie własne.

Tabela 8. Koncepcja użycia Bundeswehry zgodnie z Białymi Księgami z lat 1970²1, 1971/1972²2

\section{Ogólna koncepcja użycia sił zbrojnych RFN}

Bundeswehra stanowi narzędzie Zachodu służące odstraszaniu, wspólnemu zwalczaniu kryzysów i wspólnej obronie przed zagrożeniem ze strony Układu Warszawskiego.

Oddziały przeznacza się do wspólnych wysiłków obronnych; obowiązuje zakaz przygotowania wojny zaczepnej, możliwa jest jedynie obrona (art. 26 UZ). Zadania Bundeswehry w stanie pokoju oraz na wypadek zagrożenia i obrony mają charakter jedynie defensywny; armię przeznacza się do kontrataku taktycznego, lecz nie do ofensywy.

20 Weissbuch 1969..., s. 13, 18, 20, 24-30, 57.

21 Weisbuch 1970 zur Sicherheit der Bundesrepublik Deutschland und zur Lage der Bundeswehr, Bonn 1970, s. $27,37-45,58-62$.

22 Weisbuch 1971/1972 zur Sicherheit der Bundesrepublik Deutschland und zur Entwicklung der Bundeswehr, Bonn 1971, s. 24-36, 50-51, 114-124. 


\begin{abstract}
W stanie pokoju zadaniem Bundeswehry jest powstrzymanie potencjalnego przeciwnika przed groźbą oraz użyciem przemocy dzięki stałej gotowości operacyjnej. W stanie kryzysu i zagrożenia do zadań sił zbrojnych RFN należy odstraszanie oraz zarządzanie kryzysowe. W razie zaistnienia konieczności obrony Bundeswehra broni integralności terytorialnej RFN poprzez maksymalne ograniczanie szkód i opóźnianie ataku tak, aby wydłużyć czas mobilizacji i powzięcia decyzji politycznych.

Integracja w ramach NATO: w stanie pokoju obowiązuje wspólna struktura dowódcza z wielonarodowymi dowództwami, wspólne planowanie operacyjne i prowadzenie regularnych, połączonych ćwiczeń wojskowych; w stanie obrony i w przypadku częściowej obrony powietrznej w stanie pokoju - obowiązuje wspólne dowodzenie operacyjne. Siły lądowe i powietrzne wyposażone są w nośniki broni jądrowej. Obrona terytorialna: na wypadek obrony obowiązuje utrzymywanie swobody operacyjnej wszystkich jednostek operacyjnych NATO na terytorium RFN, wsparcie działających na terytorium RFN sił zbrojnych NATO ze środków państwowych oraz uzupełnianie zasobów osobowych i materialnych niemieckich jednostek wojskowych. Postuluje się współpracę terytorialnych sił lądowych z administracją Bundeswehry oraz z urzędami cywilnymi (w tym policją i strażą graniczną).
\end{abstract}

\title{
Szczegółowe użycie sił lądowych, powietrznych i morskich
}

Siły lądowe (Heer): obrona granic Niemiec, ochrona terytorium Republiki Federalnej przed przeciwnikiem, rezygnacja z broni strategicznej, ściślejsza współpraca z Luftwaffe i Marine oraz siłami zbrojnymi Sojuszu, wypełnianie zadań związanych z obroną terytorialną.

Siły powietrzne (Luftwaffe): rozpoznanie, wsparcie konwencjonalne sił lądowych, obrona powietrzna, zwiększenie umiejętności rozpoznania zwłaszcza w czasie akcji nocnych oraz w okresie złej pogody.

Siły morskie (Marine): zwalczanie wrogich sił morskich, zwłaszcza w rejonie Bałtyku, ochrona flanki RFN od strony morza, wkład w obronę dojścia do Bałtyku oraz części Morza Północnego, ochrona zaopatrzenia z Morza Północnego, którego obszar staje się coraz ważniejszy.

Źródło: opracowanie własne.

Tabela 9. Koncepcja użycia Bundeswehry zgodnie z Białą Księgą z lat 1973/1974²3

\section{Ogólna koncepcja użycia sił zbrojnych RFN}

Nawiązanie do wojskowo-strategicznej koncepcji Bundeswehry z 1973 r. (wydawca: BMVg).

Bundeswehra stanowi instrument zabezpieczania pokoju i jednocześnie narzędzie służące polityce odprężania; do jej zadań należą: odstraszanie i zwalczanie kryzysów oraz obrona narodowa i sojusznicza. Bundeswehra stanowi największy kontyngent sił konwencjonalnych NATO w Europie.

\section{Szczegółowe użycie sił lądowych, powietrznych i morskich}

Podkreślona rola obrony na wysuniętych rubieżach.

Zaznaczona rola sił terytorialnych (Heer); do ich zadań należą: zabezpieczanie swobody operacyjnej pozostałych sił lądowych i jednostek sojuszniczych, zwalczanie napastnika, który przedostanie się na tylny obszar terytorium RFN, a także zaopatrywanie pozostałych jednostek sił lądowych w środki materialne we współpracy z administracją Bundeswehry oraz korpusem sanitarnym.

Siły powietrzne (Luftwaffe): walka przeciwko wrogim siłom powietrznym poprzez ograniczanie ich swobód taktycznych i operacyjnych, utrudnianie wzmocnienia sił wroga na tylnym obszarze terytorium, wspieranie sił lądowych w punktach zapalnych walki, wsparcie sił morskich w szczególnych przypadkach i pomoc w transporcie powietrznym, pozostawanie w gotowości do nuklearnego odstraszania, pomoc w zwalczaniu kryzysów. Siły morskie (Marine): zdobywanie informacji dotyczących zamiarów wroga odnośnie do Bałtyku i Morza Północnego, obrona terytorium RFN przed atakami na morskie wybrzeża w myśl koncepcji obrony na wysuniętych rubieżach, utrudnianie przeciwnikowi dojścia oraz korzystania z obszaru Bałtyku, jak również przepływu przez morskie obszary łączące Bałtyk z Morzem Północnym, umożliwianie transportu zasobów osobowych i materialnych otwartą drogą przez wybrzeża w ograniczonym zakresie.

Źródło: opracowanie własne.

23 Weisbuch 1973/1974 zur Sicherheit der Bundesrepublik Deutschland und zur Entwicklung der Bundeswehr, Bonn 1974, s. 29-40, 156-173. 
Tabela 10. Koncepcja użycia Bundeswehry zgodnie z Białą Księgą z lat 1975/197624

\section{Ogólna koncepcja użycia sił zbrojnych RFN}

Bundeswehra pozostaje armią o charakterze defensywnym, działającą w ramach ogólnych reguł prawa międzynarodowego, które są częścią prawa federalnego; w celu zabezpieczenia własnych interesów Bundeswehra rezygnuje z dostępu do broni $\mathrm{ABC}$; ze względu na możliwości dowódcze, jak również zasoby osobowe, materialne i zaopatrzeniowo-techniczne Bundeswehra nie nadaje się do zadań ofensywnych; żołnierze wyposażeni są oraz wyszkoleni do przeprowadzania kontrataków (atak taktyczny jest elementem defensywy strategicznej) oraz odstraszania.

Siły lądowe, powietrzne i morskie są stale obecne na obszarach operacji, ponadto oddziały sił lądowych dyslokuje się blisko granicy; wszystkie oddziały charakteryzuje wysoka mobilność oraz gotowość bojowa, a także sprawny i szybko reagujący system dowodzenia.

\section{Szczegółowe użycie sił lądowych, powietrznych i morskich}

Siły lądowe (Heer): mobilizacja znaczącej części sił lądowych wynosi 3 dni, a w przypadku kryzysów międzynarodowych - decyzja należy do dowództwa politycznego, zależnie od tego, czy jednostki sił lądowych będą brać udział w akcjach poza RFN, np. jako część wielonarodowych jednostek interwencyjnych NATO; w przypadku obrony - walczą jednostki sił lądowych podporządkowane NATO. Siły pozostające pod dowództwem narodowym zobligowane są do zapewnienia wszystkim oddziałom NATO na terenie RFN swobody operacyjnej oraz do zaopatrywania niemieckich jednostek lądowych w zasoby materialne i osobowe; pas dowodzenia lokuje się pomiędzy obszarem Niemiec północnych a obszarem centralnych gór o średniej wysokości i Przedgórzem Alpejskim.

Siły powietrzne (Luftwaffe): stała gotowość bojowa, również w stanie pokoju, ograniczanie taktycznej i operacyjnej swobody działania wrogich sił powietrznych; współpraca z siłami lądowymi i morskimi; obszar działania Luftwaffe sięga od północy do Bałtyku, od południa - do Alp, od Zachodu - do państw Beneluxu; zadania taktycznej wojny w powietrzu; rozpoznanie elektroniczne i telekomunikacyjne, kontrola przestrzeni powietrznej (porządkowanie ruchu w przestrzeni, nadzór nad ruchem, ostrzeganie); ochrona ważnych obiektów i obszarów strategicznych w kraju; atak powietrzny skierowany głównie przeciwko wrogim siłom powietrznym na ziemi, przeciwko wrogim siłom lądowym na obszarze koncentracji ich wojsk oraz przed dotarciem na pole walki, a także przeciwko wrogim siłom morskim znajdującym się w pobliżu obszarów przybrzeżnych.

Siły morskie (Marine): przeprowadzanie akcji poszukiwawczych i ratowniczych na pełnym morzu oraz na obszarach przybrzeżnych, wspieranie stosunków międzypaństwowych poprzez przeprowadzanie wizyt za granicą, wspieranie badań morskich. Włączenie okrętów marynarki RFN do stacjonujących jednostek operacyjnych NATO, rozpoznanie w stanie pokoju oraz kryzysu, gotowość operacyjna; w stanie obrony - utrudnianie przeciwnikowi przedostawania się przez Bałtyk, odpieranie ataków przez morze oraz dojścia do Bałtyku i Morza Północnego; na Morzu Północnym - zabezpieczanie drogi transportu i ochrona obszaru morskiego będącego źródłem surowców.

Źródło: opracowanie własne.

Biała Księga z lat 1975/1976 ponownie podkreśla obronny charakter armii RFN. W dokumencie (tab. 10) doprecyzowano użycie sił zbrojnych (obecność na obszarach operacji, dyslokacja, mobilność), jednocześnie zwracając uwagę na tak istotne elementy, jak system dowodzenia, reagowania i in. Sformułowano także konkretniejsze wytyczne dotyczące użycia sił lądowych, powietrznych i morskich, określając również dokładne obszary działania dla pierwszych dwóch rodzajów sił zbrojnych. Wskazuje to na intensyfikację prac nad szczegółowymi koncepcjami użycia Bundeswehry w związku z okresem zmiany jej statusu w ramach NATO.

24 Weisbuch 1975/1976 zur Sicherheit der Bundesrepublik Deutschland und zur Entwicklung der Bundeswehr, Bonn 1976, s. 81-109, 117-120. 
Tabela 11. Koncepcja użycia Bundeswehry zgodnie z Białą Księgą z 1979 r. ${ }^{25}$

\section{Ogólna koncepcja użycia sił zbrojnych RFN}

Siły zbrojne przeznaczone do obrony powietrznej - podporządkowane są już w stanie pokoju dowództwu NATO (NATO-Command); w większości niemieckie jednostki operacyjne są przydzielone NATO - w odpowiedniej fazie wymaganej gotowości bojowej podlegają albo dowództwu NATO, albo są przeznaczone do późniejszych działań. Jednostki wojsk terytorialnych pozostają pod dowództwem narodowym. Przeznaczenie do szybkiego reagowania w okresie politycznego napięcia.

\section{Szczegółowe użycie sił lądowych, powietrznych i morskich}

Siły lądowe (Heer): wzmożona aktywność w stanie pokoju; na stan obrony przewiduje się potrojenie ilości zdolnych do mobilizacji w 3 dni wojsk terytorialnych w porównaniu ze stanem ilościowym w czasie pokoju; zadania: rozpoznanie i szybkie reagowanie, walka przeciwko siłom pancernym przeciwnika, wsparcie ogniowe, obrona lotnicza.

Siły powietrzne (Luftwaffe): wysoka elastyczność w każdych warunkach pogodowych, w dzień oraz w nocy, szybka reakcja, kontrola przestrzeni powietrznej, rozpoznanie, walka przeciwko wrogim siłom powietrznym, wsparcie pozostałych rodzajów sił zbrojnych.

Siły morskie (Marine): koncentracja na północnej flance NATO, usprawniony system dowodzenia pozwalający na bardziej precyzyjne rozpoznanie.

Źródło: opracowanie własne.

Kolejna Biała Księga z 1979 r. uzupełnia jedynie nieznacznie wcześniejsze zadania Bundeswehry, koncentrując się na zagadnieniach związanych z rolą sił powietrznych i ich użyciem w stanie pokoju oraz obrony (tab. 11).

Tabela 12. Koncepcja użycia Bundeswehry zgodnie z Białą Księgą z 1985 r. ${ }^{26}$

\section{Ogólna koncepcja użycia sił zbrojnych RFN}

Podkreśla się prymat działań politycznych nadających kierunek planom wojskowym; Bundeswehra pozostaje armią sojuszniczą, wykonującą zadania jedynie w ramach NATO, nie zaś samodzielnym narzędziem RFN służącym demonstracji siły; zmniejszanie niebezpieczeństwa ataku stron Układu Warszawskiego następuje poprzez demonstrację odważnej, pewnej gotowości do obrony (system obronny wspierany jest dzięki wprowadzeniu 5-letniego amerykańskiego programu strategicznej obrony przeciwrakietowej - Strategic Defense Initiative).

W stanie pokoju istotną rolę odgrywa przygotowanie i szkolenie żołnierzy w celu osiągnięcia szybkiej gotowości bojowej; bardzo ważne jest również kształcenie polityczne; podkreśla się rolę niemieckich oficerów piastujących ważne stanowiska dowódcze w strukturze dowódczej NATO oraz biorących udział w planowaniu wojskowym na różnych płaszczyznach w wojskowych sztabach NATO.

Bundeswehra wchodzi w skład trzech jednostek interwencyjnych NATO (Standing Naval Force Atlantic, Standing Naval Force Channel, Allied Command Europe Mobile Force), charakteryzujących się wysoką mobilnością i wspólnym działaniem w zwalczaniu kryzysów; do jej zadań dodatkowych należą: szkolenie żołnierzy, testowanie nowych sprzętów oraz wielonarodowa współpraca.

Siły zbrojne RFN współpracują z jednostkami sił NATO, stacjonującymi na terenie RFN, zapewniając interoperacyjność działania armii (sprzęt, systemy uzbrojenia, szkolenie żołnierzy).

W stanie kryzysu: postuluje się zwiększony udział w operacjach przeprowadzanych przez jednostki interwencyjne oraz udział w morskich operacjach na obszarze traktatowym NATO; decyzję o ogłoszeniu gotowości bojowej podejmuje minister obrony narodowej, natomiast decyzję o ogłoszeniu mobilizacji na stan kryzysu - rząd. W stanie wojny do zadań Bundeswehry należą: ograniczanie szkód, ochrona integralności RFN oraz odstraszanie.

25 Weisbuch 1979 zur Sicherheit der Bundesrepublik Deutschland und zur Entwicklung der Bundeswehr, Bonn 1979, s. 25, 26, 145-178.

26 Weisbuch 1985 zur Lage und Entwicklung der Bundeswehr, Bonn 1985, s. 72-81, 112-125, 187-222. 
Szczegółowe użycie sił lądowych, powietrznych i morskich

Siły lądowe (Heer): w początkowej fazie ataku mają za zadanie bronić 65\% całej szerokości frontu pomiędzy Bałtykiem a granicą niemiecko-austriacką, natomiast po dołączeniu jednostek sojuszniczych - 55\%; ponadto oddziały RFN udzielają pomocy jednostkom sojuszniczym podczas ich dotarcia, przemarszu i uzyskiwania swobody operacyjnej na terenie Republiki Federalnej. W stanie pokoju najważniejsze jest szkolenie i kształcenie żołnierzy; postuluje się odbywanie manewrów wojskowych, ćwiczeń i współpracę z jednostkami sojuszniczymi; sprawnie przeprowadzona obrona na wysuniętych rubieżach możliwa jest jedynie dzięki elastycznemu dowodzeniu, odpowiedniemu wyszkoleniu żołnierzy, odpowiedniej strukturze, jak również wyposażeniu Bundeswehry.

Siły powietrzne (Luftwaffe): w stanie pokoju odbywa się szkolenie żołnierzy w celu wypełniania zadań w stanie kryzysu oraz wojny; w stanie wojny do zadań należą: taktyczna wojna powietrzna, przy świadomości inicjatywy ze strony napastnika (to napastnik wyznacza czas, miejsce oraz sposób przeprowadzenia ataku).

Siły morskie (Marine): w stanie pokoju odbywa się szkolenie żołnierzy, zadania: stacjonowanie w zagranicznych portach, niesienie pomocy humanitarnej, obrona na wysuniętych rubieżach - odpieranie ataków na wybrzeża, obrona kluczowych punktów uniemożliwiających przedostawanie się jednostek Układu Warszawskiego na Bałtyk oraz Atlantyk, a także utrzymywanie panowania w obszarach przy Morzu Północnym i Bałtyckim.

Źródło: opracowanie własne.

W dokumencie z 1985 r. (tab. 12) uściślono charakter Bundeswehry (armia obronna, sojusznicza), działającej w szerszych ramach politycznych. Podkreślono rolę odpowiedniego szkolenia oraz kształcenia żołnierzy wszystkich rodzajów sił zbrojnych i ich działalności w ramach komponentów wielonarodowych. W Białej Księdze akcenty przeniesione zostają z fazy użycia sił zbrojnych w stanie zagrożenia, kryzysu i wojny na stan pokoju, co wskazuje na moment odprężenia i jednocześnie sprzyja coraz bardziej świadomemu dążeniu do próby określenia tożsamości nowych sił zbrojnych.

\section{ZAKOŃCZENIE}

Powyższe zaprezentowanie koncepcji użycia sił zbrojnych RFN pozwala na wyprowadzenie wniosków odnośnie do ówczesnego charakteru sił zbrojnych Republiki Federalnej oraz czynników kształtujących treści strategii użycia czynnika militarnego w RFN w latach 1955-1989.

Można zauważyć, iż koncepcje strategiczne NATO, stanowiące reakcję na zmienną sytuację polityczną, wojskową i ekonomiczną i tym samym uwzględniające wizje użycia sił zbrojnych państw Sojuszu, wykorzystywane były na potrzeby tworzenia strategii użycia Bundeswehry, sprzyjając zbliżaniu narodowych rozwiązań do tych postulowanych w porozumieniach sojuszniczych. Stałym elementem łączącym wszystkie koncepcje użycia sił zbrojnych państw Sojuszu oraz użycia Bundeswehry stała się wizja połączonego działania służącego zneutralizowaniu wpływu zagrożeń i ich możliwych skutków.

W poszczególnych Białych Księgach konsekwentnie podkreślano charakter Bundeswehry jako armii silnie zakotwiczonej w Sojuszu, armii o charakterze defensywnym, której zadaniem jest zapobieganie wojnie, a w razie wystąpienia konfliktu - obrona 
terytorium RFN przed uzbrojonymi siłami przeciwnika. Ponadto siłom zbrojnym umożliwia się korzystanie z szerokiego spektrum środków w stanie pokoju, kryzysu oraz obrony/wojny, a także podejmowanie działań zmierzających do ustanowienia i utrzymania wewnętrznego bezpieczeństwa. Uwagę zwracają wskazane od początku, stopniowo uzupełniane i dookreślane w kolejnych Białych Księgach koncepcje użycia poszczególnych rodzajów sił zbrojnych RFN, mieszczące się w ramach koncepcji użycia sił zbrojnych NATO.

Mimo silnych związków obydwu koncepcji warto zauważyć jednak rozważne, lecz stanowczo przebijające się samodzielne myślenie strategiczne RFN, jak również pewne powolne kształtowanie się samodzielnej postawy wobec użycia czynnika militarnego w ramach uwarunkowań sojuszniczych ze względu na położenie geopolityczne oraz dysponowanie odpowiednim politycznym, militarnym i ekonomicznym potencjałem państwa ${ }^{27}$. Co istotne, zasadnicza ogólna wizja użycia sił zbrojnych Republiki Federalnej, a także istota zadań stawianych przed poszczególnymi ich rodzajami, przez lata pozostały takie same (zyskując jedynie bardziej samodzielny wymiar i elastyczne formy), rezultatem czego stała się spójna koncepcja osiągania większych zdolności w dziedzinie budowania bezpieczeństwa Niemiec zachodnich w oparciu o własne i sojusznicze siły konwencjonalne będące bliżej potencjalnych źródeł zagrożeń. Bez wątpienia koncepcja ta stanowiła podwaliny pod stopniowy, obserwowany po 1990 r., proces przejmowania przez Niemcy większej odpowiedzialności w kwestiach związanych z bezpieczeństwem, bazujący nie tylko na sojuszniczych, ale i własnych, nowoczesnych i efektywnych kontyngentach wojskowych, działających przede wszystkim na misjach i operacjach poza granicami kraju.

\section{BIBLIOGRAFIA}

Bericht der Bundesregierung über das Konzept der zivilen Verteidigung und das Programm für die Zeit bis 1972, Bonn 1968.

Dawidczyk A., Planowanie strategii rozwoju sit zbrojnych, Warszawa 2006, Zeszyty Naukowe Akademia Obrony Narodowej.

Diedrich T., Die militärische Grenzsicherung an der innerdeutschen Demarkationslinie und der Mauerbau 1961, [w:] Vom Kalten Krieg zur deutschen Einheit. Analysen und Zeitzeugenberichte zur deutschen Militärgeschichte 1945 bis 1995, red. B Thoss, Oldenbourg 1995.

Drogowoz I., Pancerna potega ZSRR 1945-1991, Warszawa 2001.

Frey M., Geschichte des Vietnamkriegs, München 2006.

27 Niemieccy wojskowi wypracowali własną modyfikację strategii „elastycznego reagowania”, zwaną strategiczną koncepcją „obrony wysuniętych rubieży”, w myśl której to Bundeswehrze przypaść miała decydująca rola w ewentualnym konflikcie zbrojnym. Zakładano, iż działania zbrojne będą prowadzone na możliwie najbardziej wysuniętych na wschód terenach Republiki Federalnej, co przełożyło się na plany odpowiedniego wyszkolenia żołnierzy, postawienia jednostek Bundeswehry w stan najwyżej gotowości i przygotowania ich do samodzielnego prowadzenia działań. I. Krumpelt, Das Kriegsbild der Zukunft, Bonn 1970, s. 25-51. 
Friedman N., Tajne akta zimnej wojny, przeł. P. Stachura, Warszawa 2005.

Greiner B., Die Kuba-Krise. Die Welt an der Schwelle zum Atomkrieg, München 2010.

Grundgesetz für die Bundesrepublik Deutschland. Werte und Normen für Soldaten, Berlin 2007.

Krumpelt I., Das Kriegsbild der Zukunft, Bonn 1970.

MC 3/5. The Strategic Concept for the Defense of the North Atlantic Area (3 December 1952), [w:] NATO Strategy Documents 1949-1969, red. G.W. Pedlow, Brussels 1997.

MC 14/2. Overall Strategic Concept for the Defence of the NATO Area (23 May 1957), [w:] NATO Strategy Documents 1949-1969, red. G.W. Pedlow, Brussels 1997.

MC 14/3. Overall Strategic Concept for the Defence of the NATO Area (16 January 1968), [w:] NATO Strategy Documents 1949-1969, red. G.W. Pedlow, Brussels 1997.

Polmar N., Moore K.J., Cold War Submarines. The Design and Construction of U.S. and Soviet Submarines, Washington 2003.

Soviet Economic Performance 1966-67. Materials Prepared for the Subcommittee, Washington 1969.

Traktat Pótnocnoatlantycki sporządzony w Waszyngtonie dnia 4 kwietnia 1949 r., Dz.U. 2000, nr 87, poz. 970.

Tucker S.C., The Encyclopedia of the Vietnam War. A Political, Social, and Military History, Santa Barbara, Calif. 2011.

Weissbuch 1969 zur Verteidigungspolitik der Bundesregierung, Bonn 1969.

Weißbuch 1970 zur Sicherheit der Bundesrepublik Deutschland und zur Lage der Bundeswehr, Bonn 1970.

Weißbuch 1971/1972 zur Sicherheit der Bundesrepublik Deutschland und zur Entwicklung der Bundeswehr, Bonn 1971.

Weißbuch 1973/1974 zur Sicherheit der Bundesrepublik Deutschland und zur Entwicklung der Bundeswehr, Bonn 1974.

Weißbuch 1975/1976 zur Sicherheit der Bundesrepublik Deutschland und zur Entwicklung der Bundeswehr, Bonn 1976.

Weißbuch 1979 zur Sicherheit der Bundesrepublik Deutschland und zur Entwicklung der Bundeswehr, Bonn 1979.

Weißbuch 1983 zur Sicherheit der Bundesrepublik Deutschland, Bonn 1983.

Weißbuch 1985 zur Lage und Entwicklung der Bundeswehr, Bonn 1985.

Dr Agnieszka POLOŃCZYK - doktor nauk społecznych w dyscyplinie nauki o bezpieczeństwie, adiunkt w Instytucie Bezpieczeństwa i Edukacji Obywatelskiej Uniwersytetu Pedagogicznego w Krakowie. Członek Rady Naukowej Fundacji im. Cichociemnych Spadochroniarzy Armii Krajowej. 